\title{
HARMINC ÉV A KÖZÖS ÚTON: MAGYARORSZÁG ÉS A KOREAI KÖZTÁRSASÁG
}

\author{
Thirty years on the common path for Hungary and the Republic \\ of Korea
}

\section{Fábian Armin Vincentius ${ }^{1}$ - Pajor Angelika ${ }^{2}$ - Vadas Ágoston ${ }^{3}$}

\begin{abstract}
Absztrakt: 1989-ben úttörőnek számított Magyarország és a Koreai Köztársaság bilaterális kapcsolatainak megszületése, ugyanis Magyarország volt az első olyan állam a keleti blokk országai közül, mely vállalta a konfrontációt Észak-Koreával, illetve a hozzá lojális kommunista vezetésű országokkal a déli szomszéddal való kapcsolatépítés miatt. Bár a merész lépés a kétpólusú világrend megszűnését követően kevésbé maradt forradalmi jelentôségű, a 30. évfordulót átlépve számos fontos mérföldkőre tekinthetünk vissza a két ország kapcsolatainak történetét illetően. Jelen tanulmány célja, hogy áttekintést nyújtson a két ország közötti főbb politikai, gazdasági és kulturális törekvésekről és eredményekről, továbbá felhívja a figyelmet azon kiaknázatlan lehetőségekre, melyek egyaránt megjelennek a diplomácia, a gazdaság és a kultúra világában. A jubileumi évfordulóra való tekintettel e tanulmány szerzői törekedtek arra, hogy az
\end{abstract}

\footnotetext{
${ }^{1}$ Fábian Armin Vincentius a Pázmány Péter Katolikus Egyetem nemzetközi tanulmányok mesterképzés, civilizációs és regionális specializáció hallgatója, az Eötvös Loránd Tudományegyetem Keleti nyelvek és kultúrák, koreai szakirány diplomása. Kutatási területe: Dél-Korea diplomáciai kapcsolatai, a koreai diaszpóra helyzete, továbbá a kereszténység kérdése Kelet-Ázsiában. Fábian Armin a Koreanista hírportál és a TudományON ismeretterjesztő portál főszerkesztője, továbbá a Szent Ignác Jezsuita Szakkollégium diákbizottságának korábbi alelnöke.

ORCID: https://orcid.org/0000-0002-3872-1079

2 Pajor Angelika 2018 óta a Budapesti Corvinus Egyetem hallgatója nemzetközi tanulmányok alapszakon, továbbá a Szent Ignác Jezsuita Szakkollégium szakkollégistája. Érdeklődési körébe tartozik az európai integráció, a kritikai geopolitika különböző elméletei, illetve a civilizációk fejlődése és annak hatásai egymásra.

3 Vadas Ágoston szigorló orvos a Semmelweis Egyetemen, kutatási témája a térdízületi porcfelszínek rekonstrukciós lehetőségei, illetve ezek tökéletesítése a mesterséges intelligencia felhasználásával. Korábban tanult az Egyesült Államokban, a nemzetközi kapcsolatok tematikáját pedig a Szent Ignác Jezsuita Szakkollégium szervezésében megvalósuló Geopolitika kurzus keretén belül vizsgálta részletesen.
} 
ünnepi időszakhoz méltóan a gazdasági és politikai történéseken túl szót ejtsenek a kulturális találkozás főbb megnyilvánulásairól és sikereiről, továbbá olyan interjúrészleteket közöljenek egy-egy koreai és magyar szereplővel, amelyek felhívják a figyelmet a két nemzet közötti meglepő közelségre.

Kulcsszavak: Dél-Korea, Magyarország, 30. évforduló, diplomácia, bilaterális kapcsolatok

Abstract: In 1989 the establishment of bilateral relations between Hungary and the Republic of Korea was considered a path-breaker decision, as Hungary became the first country of the Eastern Bloc to engage in a conflict with the Democratic People's Republic of Korea and the loyal socialist states by communicating directly with South Korea. Athough the bold move has become less revolutionary since the end of Bipolarity and the Cold War, crossing the 30th anniversary of the diplomatic relations between the two countries means that we can look back on a number of important milestones. The aim of this study is to provide an overview of the main political, economic and cultural aspirations and achievements during the 30 years, as well as to draw attention to the unexploited opportunities that emerge in various areas, like diplomacy, economy and culture. Taking into consideration the 30 years of successful diplomatic ties between the two countries. the authors of this article seek to mention the main manifestations and successes of the cultural proximity of the nations by including interviews made with Korean and Hungarian individuals as well.

Keywords: South Korea, Hungary, 30th anniversary, diplomacy, bilateral relations

\section{BEVEZETÉS}

Az államok közötti kapcsolatok kibontakozását és fejlődését számos tényező nehezítette a második világháborút követő időszakban, még úgy is, hogy a világméretű konfliktust a nemzetközi kapcsolatok fellendülése követte. A kétpólusú világ kiépülése ugyanis erőteljes közeledést eredményezett az adott pólushoz tartozó tagok között, ám gátat szabott az ebből való kilépés lehetőségének. Ez a jelenség meghatározta Magyarország és a 
Koreai Köztársaság ${ }^{4}$ közötti kapcsolatokat is, mely a század második felében közel 40 éven keresztül gyakorlatilag nem is létezett. A kétpólusú világrend meggyengülése, majd szétbomlása azonban teret adott többek között a két ország kapcsolatfelvételének is, amely az elmúlt több mint 30 évben számos változáson ment keresztül. Jelen tanulmány célja, hogy a magyar-dél-koreai kapcsolatfelvétel jubileumi 30. évfordulóját átlépve válaszokat adjon azon kérdésekre, hogy miként alakult a két ország közti politikai, gazdasági és kulturális kapcsolatok dinamikája, milyen előrelépések és fejlesztések várhatóak a jövőben a korábbi évek tendenciái alapján, továbbá mit adhat egymásnak és milyen szerepet játszhat egymás életben két ilyen különböző kultúrával, gazdasági és földrajzi adottságokkal rendelkező állam.

Jelen munka során három egymástól elkülönített fejezetrészben kerülnek bemutatásra a két ország közötti kapcsolat politikai, gazdasági és kulturális szegmensei. A politikai rész egy rövid történelmi áttekintés keretén belül mutatja be a második világháborút követően a két ország eltérô útját, majd az 1980-as évek második felében bekövetkező kapcsolatépítés első lépéseit, továbbá az elmúlt 30 év jelentős és releváns politikai mérföldköveteit. Ezen felül szó esik Dél-Korea jelenlétéről KözépEurópában - különösen a visegrádi országok viszonylatában -, továbbá a magyar-dél-koreai kapcsolatok jelentőségéről a magyar-kínai, illetve magyar-japán kapcsolatok tükrében. A gazdasági fejezeten belül áttekintésre kerül a két ország jelenlegi gazdasági helyzete, ahogy szó esik az államok közötti együttműködés főbb gazdasági mozgatóerejéről is. E tanulmány zárófejezetének központi témája a kultúra: az oktatási intézményeken és intézményesített kulturális téren kapcsolatépítő hálózatokon túl pedig arra is válasz kerestetik, hogy milyen módon érte el az úgynevezett koreai hullám Magyarországot, továbbá miként tud Magyarország lépéseket tenni a kulturális egyensúly kialakítása érdekében. A diplomáciai kapcsolatok felvételének és politikai körülményeinek vizsgálata, a jelenkori gazdasági folyamatok elemzése és a kulturális kapcsolódások megértése elvezet azon kérdéshez, mely a magasabb volumenű együttműködés lehetőségeit keresi hazánk és a Koreai-félsziget között.

${ }^{4}$ A továbbiak során Koreai Köztársaság, illetve Dél-Korea. 


\section{Politikai kapcsolatok}

\subsection{Magyar Népköztársaság és a Koreai Köztársaság a háborút követően}

A II. világháború (1939-1945) lezárását a szovjet megszállás hozta el Magyarország számára. Az 1946. február 1-jén kikiáltott Magyar Köztársaságot a fokozatosan egyre nagyobb hatalmat szerző Magyar Kommunista Párt kezdte átszervezni, majd 1949. augusztus 20-án kikiáltották a Magyar Népköztársaságot, mely az elkövetkező közel négy évtized során a Szovjetunió politikáját követte. A II. világháborút követően a Koreai-félsziget a szövetségesek erőfeszítéseinek köszönhetően felszabadult a japán gyarmati uralom alól: a 38. szélességi foktól „északra a Szovjetunió, mig attól délre az. Amerikai Egyesült Allamok szuervezte meg az ideiglenes katonai közigazgatást. Mosžkva 1945 után a kommunista Kim Ir Szent segitette hatalomra, mig Washington a déli zónában Li Szin Mant támogatta". Ezzel egyidejûleg két ellentétes folyamat is indult: míg Kim Ir Szen a szovjet mintát követte, addig Li Szin Man nyugati típusú fejlődést folytatott a félsziget déli részén. A megszállási zónák határán gyakoriak voltak az incidensek, amelyek végül 1950-ben a koreai háború (1950-1953) kirobbanásához vezettek. Mindeközben a két szögesen ellentétes ideológiát követő nagyhatalom között fokozatosan kibontakozott a hidegháború: a közvetlen fegyveres konfliktus helyett a helyi konfliktusok ellentétes oldalát támogatták, így Észak-Koreát a Szovjetunió - és Kína -, míg Dél-Koreát az Egyesült Államok és szövetségesei segítették. A két fél végül 1953. július 27én megkötötte a panmindzsoni fegyverszünetet - a békekötés azonban napjainkig sem történt meg. ${ }^{6}$

Az előzmények ismeretében nem okoz meglepetést, hogy Magyarországnak és Dél-Koreának egészen az 1980-as évekig nem voltak számottevő diplomáciai kapcsolatai, hiszen előbbi kizárólag a vele azonos ideológiát valló Észak-Koreát, azaz a Koreai Népi Demokratikus Köztársaságot ismerte el, mint a félsziget törvényes államát. Ennek ellenére említésre méltóak az 1956-os események, melyek során a dél-koreai államvezetés együttérzésről és támogatásáról biztosította Magyarországot, dél-koreai egyetemi hallgatók pedig szabadcsapatok megszervezését

\footnotetext{
${ }^{5}$ RubiCON, 2017.

${ }^{6}$ RUBICON, 2017.
} 
tervezték, hogy Budapesten harcoljanak - bár a Magyarországra történő utazásuk érthető módon nem valósulhatott meg, hiszen a dél-koreai fél attól tartott, hogy egy ilyen történés akár jelentős nemzetközi konfliktust eredményezhet. $^{7}$

\subsection{A kétoldalú kapcsolatok első lépései}

A két ország először az 1980-as években vette fel a kapcsolatot egymással, az első kezdeményezés pedig 1983-ban valósult meg: az Interparlamentáris Unió 70. közgyűlésére Szöulban került sor, ahova Magyarország is meghívást kapott, ám a részvétel végül Moszkva utasítására elmaradt. Az évtized második felében már a magyar politikai elit is másképp viszonyult a Dél-Koreával való kapcsolatfelvételhez: Torzsa István beszámolója alapján Kótai Géza, az MSZMP KB Külügyi Osztályának vezetője Várkonyi Péter külügyminiszterhez 1987-ben írt levelében jelzést adott a kamarai képviseletek felállításáról szóló tárgyalásoknak. ${ }^{8}$ 1988-ban Bartha Ferenc, a Magyar Nemzeti Bank elnöke és Lőrincze Péter, a Magyar Gazdasági Kamara főtitkára többször is Szöulba látogatott, hogy ott a kamarai képviseletek megnyitásáról tárgyaljanak. Ezeknél is fontosabb lépés volt, hogy ugyanezen év júniusában Demján Sándor, a Magyar Hitelbank elnöke is Szöulba utazott, ahol biztosította az ország vezetését, hogy Magyarország kész a diplomáciai kapcsolat felvételére Dél-Koreával, amennyiben az hajlandó aláírni egy egymilliárd dollár értékű gazdasági csomagot. Alig néhány héttel később, július 5-én Park Chul Un elnöki politikai tanácsadó titokban Budapestre látogatott, ahol tárgyalásokat kezdett Bartha Ferenccel: előbbi 400 millió dollár hitelt ajánlott fel, utóbbi pedig 800 millió dollárra csökkentette az elvárásait. Park Chul Un Grósz Károlyt is meglátogatta és tájékoztatta Roh Tae Woo elnök külpolitikai terveiről, melyek a két Korea egyesítését célozták meg. Az ezen célhoz kidolgozott programtervezet az úgynevezett „északi politika” volt, mely hivatalosan 1988. július 7-én vette kezdetét. Az „északi politika” csak egyik fele vonatkozott Észak-Koreára, a másik része a volt szocialista tömb országaival való kapcsolatfelvételt szorgalmazta. ${ }^{10}$

\footnotetext{
${ }^{7}$ CSOMA, 2012. 53-59.o

8 TORZSA, 2009. 213.o.

9 TORZSA, 2009. 213.o

${ }^{10}$ TORZSA, 2009. 214.o
} 
Augusztus 8-a és 12-e között Bartha Ferenc vezetésével újabb küldöttség járt Szöulban, ahol megállapodás született arról, hogy hat hónapon belül teljeskörű diplomáciai viszonyt alakít ki egymással a két ország. Bő egy héttel később, augusztus 25-én Park Chul Un újból Budapestre látogatott, ahol abban állapodott meg a magyar külügyminisztérium képviselójével, hogy a két állam kapcsolatát két lépcsőben fogják rendezni, ennek legfőbb oka pedig az volt, hogy Magyarországnak el kellett fogadtatnia a döntést a szovjet blokk államainak vezetőivel. „Ezt tudomásul véve született az a kompromisszum, amelynek eredménye volt a politikai kapcsolatok normalizálásáról 1988. angusztus 26-án alaírt azon megállapodás ${ }^{11},(. .$.$) amelynek alapján a felek állandó képviseletet állithattak fel egymás$ fövárosában, s egyidejüleg kötelezték magukat, hogy a legrövidebb idön belül tárgyalásokat keqdenek a teljes körü diplomáciai kapcsolatok felvételéröl". ${ }^{12} \mathrm{Nem}$ elhanyagolható a tény, hogy dokumentumot többek között a magyar-délkoreai kapcsolatfelvétel egyik legfőbb támogatója, Horn Gyula külügyi államtitkár is aláírta. Az egyezmény kitért egy gazdasági megállapodásra is a két fél között, mely keretén belül Dél-Korea 625 millió dollár hitelt ajánlott fel - ami bár elmaradt a magyar fél elsődleges igényeitôl, ám mégis komoly támogatásnak bizonyult. A megállapodás szeptember 13-án lépett hatályba, melynek alkalmából Etre Sándor, a Külügyminisztérium illetékes területi föosztályának helyettese Szöulba utazott. Még ez év októberében megnyílt Budapesten a Fórum Szállóban Dél-Korea Állandó Képviselete, majd két hónappal később Szöulban, a Hilton Szállóban Magyarország Állandó Képviselete. $^{13}$

Az esemény kimagasló jelentőséggel bírt: Magyarország volt az első szocialista ország, mellyel a Koreai Köztársaság felvette a kapcsolatot. Az esemény hatalmas visszhangot váltott ki világszerte: míg a nyugati berendezkedésű, kapitalista országok egytől-egyig üdvözölték a hírt, addig a keleti blokk véleménye már jóval vegyesebb volt. Bár több ország - köztük a Szovjetunió, Csehszlovákia, Jugoszlávia és Lengyelország hallgatólagosan támogatta azt, mások - mint például Románia és az NDK határozottan ellenezte, amiben nagy szerepet játszott Ceausescu és Honecker baráti viszonya Kim Ir Szennel. Észak-Korea különösen

\footnotetext{
11 Magyar részről dr. Görög János, a Külügyminisztérium Nemzetközi Jogi Főosztályának vezetője, koreai részről Min Hyung-Ki, a Külügyminisztérium Európai Főosztályának vezetője volt az aláíró.

12 TORZSA, 2009. 218-219.o.

13 TORZSA, 2009. 219.o.
} 
sérelmezte Magyarország nyitását Dél-Korea felé: ez odáig fajult, hogy Kim Ir Szen visszahívta Észak-Korea magyarországi nagykövetét, Kim Pjong Ilt - aki nem más volt, mint Kim Ir Szen testvére.

A nehezítő körülmények ellenére a tárgyalások hamarosan eredményesen zárultak: „Horn Gyula külïgyminisztériumi államtitkár 1989. február 1-én Szöulban aláirta a Magyar Népköztársaság és a Koreai Köztársaság közötti, teljes körü diplomáciai kapcsolatok felvételéról szóló jegyzőkönyvet, amelynek. alapján az addigi állandó képviseletek nagykeövetségi rangra emelkedtek.". "További szerződések is aláírásra kerültek, például a kulturális egyezmény, a kereskedelmi és gazdasági együttműködési megállapodás és a diplomáciai és szolgálati útlevelekre vonatkozó vízummentességi megállapodás. Az eredményes diplomáciai kapcsolatfelvétel a korábbinál is hevesebb visszhangot váltott ki az észak-koreai sajtóból, amely nyíltan becsmérelte és fenyegette hazánkat. A magyar nagykövetet, Kornidesz Mihályt behívatták a Külügyminisztériumba és felszólították az ország elhagyására. Mindeközben Szöulban a terrorelhárítók egyik 30-40 fős speciális egysége védte a magyar missziót, amelyet végül - valószínúleg részben épp ezért - nem ért támadás. ${ }^{15}$

\subsection{Magyarország és Dél-Korea viszonya a diplomáciai kapcsolatok felvételét követően}

Már az állandó képviseletek felállításáról szóló szerződést követően felélénkültek a politikai kapcsolatok a két ország között. Az akkori külügyminiszter, Várkonyi Péter az ENSZ Közgyűlés 43. ülésszakán, továbbá a vegyi fegyverek betiltásáról szóló párizsi kongresszuson is találkozott és konzultált a dél-koreai külügyminiszterrel, Choi Hoo Joonggal. Novemberben a sportminiszter is látogatást tett Budapesten, majd egy hónappal később Shin Dong Won, első külügyminiszter-helyettes járt Magyarországon, hogy sor kerülhessen a beruházásvédelmi egyezmény aláírására. 1989 tavaszán Budapestre érkezett Choi Hoo Joong, akinek jelenlétében aláírták a kettős adóztatás kizárásáról szóló egyezményt ${ }^{16}$.

Ezt követően az élet majd minden területére kiterjedő szerződéskötések következtek: született légügyi, állat-egészségügyi és

\footnotetext{
14 TORZSA, 2009. 220.o.

15 TORZSA, 2009. 221.o.

16 TORZSA, 2009. 220.o.
} 
idegenforgalmi megállapodás is, ahogy a két állam tudományos akadémiái és felsőoktatási intézményei is felvették egymással a kapcsolatot. Ugyanez történt a két parlament tekintetében is: 1989 decemberében magyar országgyűlési küldöttség járt Szöulban, majd 1991 májusában egy többpárti delegáció is odautazott Szabad György, az Országgyűlés elnöke vezetésével. Az akkori magyar külügyminiszter, Jeszenszky Géza 1991 tavaszán viszonozta Choi Hoo Joong látogatását, mely látogatás során sor került a teljes körű vízummenteségi egyezmény aláírására. ${ }^{17}$

Az elkövetkező években rendszeressé váltak a magas szintű látogatások: Dél-Koreából Kim Dae-jong köztársasági elnök 2001-ben, a törvényhozás elnöke 2002-ben érkezett Magyarországra. 2004-ben a kormányfő, Lee Hae-chan részt vett a Balatonőszödön megtartott Haladó Kormányzás nevet viselő konferencián. 2005-ben Ban Ki-mun külügyminiszter, akkori ENSZ-főtitkár érkezett Budapestre. Az 1990-es években Göncz Árpád köztársasági elnök és Horn Gyula miniszterelnök tett látogatást Szöulban. 2002-ben Orbán Viktor járt Dél-Koreában nem hivatalos célból, 2005-ben Gyurcsány Ferenc akkori miniszterelnök, 2006ban Szili Katalin, az Országgyúlés elnöke, 2007-ben pedig Göncz Kinga külügyminiszter látogatott Szöulba. ${ }^{18}$

Gyurcsány Ferenc látogatásának elsődleges motivációja az volt, hogy visszaállítsa a dél-koreai befektetők megcsappant bizalmát, ezért a legmagasabb szinten történt kapcsolatfelvétel dél-koreai óriáscégek vezetőivel. Egy évvel később a Szili Katalin által vezetett delegáció a Hankook Tire egyik dél-koreai gyárában vette szemügyre, milyen gyár fog Magyarországon épülni. Göncz Kinga látogatása arra szolgált, hogy áttekintésre kerüljenek az elmúlt 19 év eredményei. A látogatás egészen egyedinek tekinthető: Göncz felkereste az észak-koreai Keszongot, melynek közvetlen szomszédságában található egy dél-koreai ipari park. Az északkoreai hatóságok meglepően rugalmasan kezelték a magyar ötletet, ami így minden konfliktus nélkül zajlott le. Áder János köztársasági elnök 2015 áprilisában Szöulba utazott, ahol bejelentette, hogy az ország érdeke szorosabbra füzni a kapcsolatot Dél-Koreával, aminek egy Budapest-Szöul közvetlen járat is a részét képezné. ${ }^{19}$

17 TORZSA, 2009. 221.o.

18 TORZSA, 2009. 222.o.

19 TORZSA, 2009. 223.o. 


\subsection{Dél-Korea megállapodása a Visegrádi Négyekkel}

Hosszú diplomáciai egyeztetések után 2015. december 3-án a négy visegrádi állam - Csehország, Lengyelország, Magyarország és Szlovákia megállapodást kötött Dél-Koreával, mely megállapodásban szó esett különböző alapelvekről, közös és regionális együttműködésről, gyakorlati lépésekről, valamint világpolitikával kapcsolatos ügyekhez való hozzáállásról is. Csehország miniszterelnöke, Bohuslav Sobotka, Lengyelország miniszterelnöke, Beata Szydło, Magyarország miniszterelnöke, Orbán Viktor, Szlovákia miniszterelnöke, Robert Fico és Dél-Korea elnöke, Park Geun-hye Prágában írták alá a 38 bekezdésből álló szerződést.

Az első bekezdésekben az aláiró felek megerősítették a partnerség alapelveit és alapértékeit - melyek közé tartoztak az alapvető emberi jogok, a demokrácia, a piacgazdaság és jogállamiság -, továbbá kiemelték DélKorea és az Európai Unió stratégiai partnerségét, illetve kifejezték igényüket a gyakoribb politikai párbeszédre, a közös együttműködésre, valamint a rendszeres közös külügyminiszteri találkozókra. A negyedik bekezdéstől az egyezmény rátér az országok gazdasági kapcsolatára is. A visegrádi országok kifejezték köszönetüket, hogy a Koreai Köztársaság támogatta a Nemzetközi Visegrádi Alapot, továbbá tájékoztatta azt a Nyugat-balkáni Alap létrehozásáról, felkérve Dél-Koreát, hogy fontolja meg támogatását. A partnerek rögzítették, hogy kölcsönösen előnyös együttműködést kötöttek, ahogy elismerték az EU-Korea Szabadkereskedelmi Egyezményt. A két fél megállapodott abban, hogy a jövőben a partnerség jegyében törekedni fognak a kereskedelem fenntartható építésére, illetve a beruházások számának növelésére - mindezt kreatív és innovatív módszerekkel -, emellett rögzítették a két fél energiaügyi együttműködésének, a globális és regionális energiaügyről alkotott véleménycserének a fontosságát is. ${ }^{20}$

A megállapodás kitér a közép- és kelet-európai országok infrastrukturális fejlesztésének fontosságára a problémamentes kereskedelem lebonyolításának érdekében, a tagok pedig fontolóra vették egy magas szintű infrastruktúra-találkozó létrehozását az infrastrukturális fejlesztések részletezésének érdekében, miközben elismerték a kis- és középvállalkozások előre mozdításának fontosságát. Az egyezmény a 14. bekezdésben rátér a partnerek kulturális együttmúködésére: a felek elkötelezték magukat az állampolgárok mobilitásának és a kreatív iparágak -

20 The Visegrad Group, 2015. 
főképp a mûvészetek: irodalom, képzőmúvészet, zene - kétoldalú együttmûködésének elôsegítése mellett. A célok között szerepelt a turizmus és az idegenforgalom előmozdítása a felek között, melyet a résztvevő országok régiói és városai közti nemzetközi partnerség ösztönzésével kívánnak elérni. Nagy hangsúlyt kapott a kutatók és diákok mobilitásának előmozdítása, továbbá a cseh, lengyel, magyar, szlovák és koreai nyelv, történelem, illetve kulturális örökség oktatása. A partnerek megerősítették szándékukat abban, hogy fokozzák a szakértelem- és a tapasztalatcserét az oktatás minőségének növelése érdekében. ${ }^{21}$

Az egyezmény második fele rátér a regionális és globális problémákra, melyek megoldása mellett a felek közösen kötelezték el magukat. Az öt állam rögzítette, hogy teljes mértékben elítéli a Koreai Népi Demokratikus Köztársaság minden félelem- és feszültségkeltő lépését, elsősorban a nukleáris és ballisztikus rakétavédelmi programjának folyamatos fejlesztését. Ezen felül felszólították Észak-Koreát, hogy haladéktalanul függessze fel e tevékenységeit, és folytasson az ENSZ Biztonsági Tanácsának határozatainak megfelelő külpolitikát. Az öt állam szorgalmazta a hatoldalú tárgyalásokat és sürgette Észak-Koreát a diplomáciai kapcsolatok felvételére. A felek kifejezték aggodalmukat az észak-koreai emberi jogi helyzettel kapcsolatban és sürgették Észak-Koreát, hogy hajtsa végre az ENSZ 2014es jelentésének javaslatait. A visegrádi államok támogatták a Koreai-félsziget békés egységesítését és egyesülését. Az öt állam elismerte a Semleges Nemzetek Felügyeleti Bizottságának jogosultságát a demilitarizált övezet mentén, továbbá a békefenntartási folyamatban betöltött munkáját is értékesnek tekintette. 22

Számunkra az egyik legkiemelkedőbb részlet a megállapodás 26. bekezdése, mely rögzíti a visegrádi országok egyedülálló tapasztalatát az 1990-es évek sikeres átmenetében. A bekezdés szerint szükség van a Visegrádi Négyek 1990-es évekbeli tapasztalatára, az ezzel kapcsolatos beszélgetések folytatására, ugyanis ezeket alkalmazni lehet a későbbiekben a Koreai-félsziget békés egyesítése során. A megállapodásban megerősítésre kerültek az északkelet-ázsiai kapcsolatok is, a V4 országok pedig elismerték és nagyra értékelték a háromoldalú csúcstalálkozót Dél-Korea, Japán és Kína között. Regionális politika terén minden fél egyetértett az eurázsiai kapcsolatok támogatásában és szorosabbra füzésében, továbbá egyöntetűen

\footnotetext{
21 The Visegrad Group, 2015.

22 The Visegrad Group, 2015.
} 
támogatták az Ukrajnában zajló reformfolyamatokat, és kifejezték egyetértésüket, hogy a kelet-ukrajnai konfliktus csak békés úton kerülhet rendezésre. A visegrádi országok és Dél-Korea a migrációval kapcsolatban is közös álláspontot képviselt: szoros együttműködést szerettek volna a tranzitországokkal, továbbá elengedhetetlennek tartották a Közel-Kelet konfliktusainak békés úton történő tartós rendezését. A megállapodás utolsó bekezdéseiben rögzítették azt a szándékot, hogy a regionális és nemzetközi szervezetekben megerősítsék együttmúködésüket, továbbá elítéljék a terrorizmust, támogassák az éghajlatváltozás elleni küzdelmet és üdvözöljék az Addisz-Abeba Cselekvési Menetrendet. ${ }^{23}$

\subsection{A magyar-dél-koreai viszony a magyar-japán és a magyar- kínai kapcsolatok relációjában}

Könnyebben értelmezhetjük Magyarország és Dél-Korea politikai kapcsolatát, ha összehasonlítjuk a két legjelentősebb kelet-ázsiai állam, Japán és Kína hazánkkal folytatott kapcsolatával. Japán és Magyarország között a diplomáciai kapcsolat egészen 1869-ig nyúlik vissza, és bár a II. világháború során a felek ugyanazon oldalon álltak, azt követően ellentétes fejlődést folytattak. Az ideológiai szembenállás ellenére a világháborút követően megindult egyfajta gazdasági kapcsolatfelvétel: magyar kereskedelmi kirendeltség nyílt Tokióban, az államok pedig évente megújításra kerülő kereskedelmi és fizetési megállapodást kötöttek. 1960-ban mindkét országban követség került megnyitásra, négy évvel később ezeket nagyköveti rangra is fokozták. A két ország között rendszeresek voltak a miniszterelnöki szintű találkozók is: 1985-ben Lázár György, 1991-ben Antall József, 1995-ben Horn Gyula, 2004-ben pedig Gyurcsány Ferenc látogatott Japánba, miközben japán oldalról Kaifu Toshiki miniszterelnök látogatott Magyarországra 1990-ben. ${ }^{24}$

A Kínai Népköztársasággal való kapcsolatfelvételre 1949 októberében került sor. A hidegháború első évtizedében a két állam szoros kapcsolatot tartott fenn, az 1950-es években pedig több magas szintű találkozóra is sor került: Csu Te alelnök kétszer, Csou En-laj miniszterelnök egyszer járt Magyarországon, míg magyar oldalról Kádár János főtitkár és Münnich Ferenc miniszterelnök tett látogatást Kínában - utóbbi aláírta a kínai-

\footnotetext{
23 THE VisEgRAD GROUP, 2015.

${ }^{24}$ MagyarorszáG-JapÁn Jubileumi Év 2009, 2009.
} 
magyar baráti együttműködési szerződést. Az 1960-as években a két állam eltávolodott egymástól, az állam- és pártközi kapcsolatok a '80-as években normalizálódtak, majd megkezdődött a kétoldalú kereskedelmi és gazdasági együttműködés. A rendszerváltást követően rendszeressé váltak a magas szintű találkozók: járt Magyarországon Zou Jiahua miniszterelnök-helyettes, Li Lanqing miniszterelnök-helyettes, Tang Jiaxuan külügyminiszter, Lio Kocsiang miniszterelnök. Magyar oldalról többek között Szűrös Mátyás, az Országgyưlés alelnöke, Jeszenszky Géza külügyminiszter, Kovács László külügyminiszter, Szili Katalin, az Országgyúlés alelnöke, továbbá Medgyessy Péter miniszterelnök tett látogatást Kínában. Napjainkban Kína prioritást élvez a magyar külpolitikában és gazdaságpolitikában a keleti nyitás tükrében, Magyarország számára ugyanis többek között Kína az első számú EU-n kívüli kereskedelmi partner. ${ }^{25}$

Míg 30 évvel ezelőtt Magyarország volt az első szocialista ország, amellyel Dél-Korea felvette a kapcsolatot, ma már a két ország közti kapcsolat közel sem nevezhető radikálisan különlegesnek régiós összehasonlításban. Az utóbbi évtizedekben Dél-Korea középhatalommá fejlődött, így igyekezett kapcsolatot ápolni a térség összes tagállamával, Magyarország számára pedig sok esetben jelentősebbé vált a Japánnal és legfőképp Kínával való szoros kapcsolat létrehozása és fejlesztése. A magyar-dél-koreai diplomáciai kapcsolatok felélénkülését egy szerencsétlen tragédia lendítette fel: a Hableány nevű, 33 dél-koreai utast szállító sétahajó szenvedett tragikus balesetet a Margit híd közelében. Bár a tragédiát követően számos kritika érkezett Dél-Korea felől a körülményeket illetően, a két kormány végig szorosan együttmúködött az ezt követő időszakban ahogy erôteljes politikai gesztus volt a két fél részvételével Budapesten megtartott egy éves megemlékezés is. ${ }^{26}$

\section{GAZDASÁGI KAPCSOLATOK}

Magyarország a keleti nyitás politikájának meghirdetését követően, 2015-ben a visegrádi országokkal együtt tett vállalást arra, hogy politikai és kulturális kapcsolatai mellett gazdasági kapcsolatait is szorosabbra füzi a Koreai Köztársasággal.

25 Chinaembassy, 2004.

26 INDEX, 2020. 


\subsection{A két ország gazdasági állapota}

Dél-Korea 2020-ban a világ 12. legnagyobb világgazdaságának számít a Nemzetközi Valutaalap adatai alapján, a világgazdaság több mint 1.5\%-át adva vásárlóerő-paritáson számolva ${ }^{27}$. Magyarország ugyanezen szempontot számolva 2018-ban 0,23\%-át adta a világgazdaságnak ${ }^{28}$. Magyarország és Dél-Korea Lengyelországgal együtt csatlakozott 1996-ban az OECD nevü szervezethez, mely a Marshall-terv kivitelezésére megalakult Európai Gazdasági Együttmúködési Szervezet jogutódja és 36 tagországot számlál. Az OECD adatai alapján Dél-Korea GDP volumene - az OECD átlagához képest nagyobb mértékben - 1989 óta (az 1998-as év kivételével) folyamatosan emelkedett, Magyarország GDP volumene 1989 óta ennél kisebb mértékben, de szintén majdnem folyamatos növekedésen ment keresztül. Magyarország gazdaságát a 2008-as gazdasági világválság láthatóan jobban sújtotta, Dél-Korea ebből a szempontból világviszonylatban is kiemelkedő, hiszen a válság közben és az azt követő években is növelni tudta gazdasági teljesítményét. ${ }^{29}$

\begin{tabular}{|l|c|c|}
\hline \multicolumn{3}{|c|}{ GDP változása az előző évihez képest (\%) } \\
\hline & Magyarország & Korea \\
\hline $\mathbf{1 9 9 2}$ & $-3,1$ & 6,2 \\
\hline $\mathbf{1 9 9 5}$ & 1,5 & 9,6 \\
\hline $\mathbf{2 0 0 0}$ & 4,4 & 8,9 \\
\hline $\mathbf{2 0 0 5}$ & 4,5 & 3,9 \\
\hline $\mathbf{2 0 1 0}$ & 0,60 & 6,5 \\
\hline $\mathbf{2 0 1 5}$ & 3,48 & 2,79 \\
\hline $\mathbf{2 0 1 6}$ & 2,18 & 2,93 \\
\hline $\mathbf{2 0 1 7}$ & 4,31 & 3,06 \\
\hline $\mathbf{2 0 1 8}$ & 2,69 & 4,98 \\
\hline
\end{tabular}

1. sz. táblázat. A GDP változása 1992 és 2018 között. OECD adatok alapján saját szerkesztés.

IMF, 2020.

28 IMF, 2020.

${ }^{29}$ OECD, 2019. 


\subsection{Exportmérleg}

A legfrissebb adatok szerint 2018-ban Dél-Korea a 30. legnagyobb export piaca volt Magyarországnak - 0,4\%-a az összes exportnak -, és a 14. legnagyobb import piaca - 1,8\%-a az összes importnak. Dél-Korea számára Magyarország a 36. legnagyobb exportpiac volt ugyanebben az évben 0,3\%-a az összes exportnak -, és az 51. legnagyobb importpiaca - 0,1\%-a az összes importnak. 2018-ben Magyarország 436 millió dollár értékben exportált termékeket Dél-Koreának, míg Dél-Korea 2000 millió dollár értékű exportkereskedelmet folytatott ugyanezen évben Magyarországgal. A Comtrade adatai alapján a két ország közötti kereskedelem 1992-ig vezethető vissza számszerúsítve. Az 1992-2018-as intervallumban az egyik legjelentősebb exportnövekedést az országok között 2003-2004-ben láthatjuk. Magyarország csatlakozása az Európai Unióhoz 2004-ben egyike lehet azoknak a hatásoknak, melyek pozitív irányba mozdították a két ország közötti gazdasági kapcsolatokat. 2015 óta az exportforgalomban fellelhető egy trend, mely Magyarország termék-külkereskedelmi egyenlegének javulását jelzi Koreával kapcsolatban. ${ }^{30}$

\begin{tabular}{|l|c|c|}
\hline & Magyarország export (millió \$) & Korea export (millió \$) \\
\hline $\mathbf{1 9 9 2}$ & 13 & 62,2 \\
\hline $\mathbf{1 9 9 5}$ & 8,6 & 168,6 \\
\hline $\mathbf{2 0 0 0}$ & 48,6 & 180,1 \\
\hline $\mathbf{2 0 0 5}$ & 126,4 & 1100 \\
\hline $\mathbf{2 0 1 0}$ & 295,4 & 2400 \\
\hline $\mathbf{2 0 1 5}$ & 483,7 & 1000 \\
\hline $\mathbf{2 0 1 6}$ & 481,2 & 953,2 \\
\hline $\mathbf{2 0 1 7}$ & 479 & 1200 \\
\hline $\mathbf{2 0 1 8}$ & 436 & 2000 \\
\hline
\end{tabular}

2. sz. táblázat. Magyarország és Dél-Korea termékforgalma. OECD adatok alapján saját szerkesztés.

30 OECD, 2020. 
Az exporttermékek szektoriális megoszlásából látható, hogy a 2018ban Magyarországról Koreába exportált cikkek közül a legnagyobb volumenúek az elektronikai felszerelések voltak, mely az exporttermékek között évekre visszamenőleg előkelő helyen áll, azonban utoljára 2011-ben volt a legjelentősebb exporttermékünk. A második legnagyobb volumenú a járművek forgalma, amely 2014-ről 2015-re jelentős növekedést mutatott, 2015 óta pedig folyamatosan növekedve érte el a 2017-es eddigi maximumát, 152.5 millió dollárt ${ }^{31}$, ahonnan 2018-ra visszaesett 45 millió dollárral. A nukleáris reaktorok alkatrészei, a különböző bojlerek, gépek exportja a 2015-ös hirtelen növekedés után csökkenő tendenciát mutat, 2017-ben más csak a második, 2018-ban pedig a harmadik legjelentősebb exporttermékünk volt Dél-Korea felé. Érdekes összefüggés továbbá a kulturális kapcsolatok erősödésének indikátoraként is felfogható kerámiaexport-növekedés, melynek következtében 2015 óta a magyar kerámiák a top 10 exporttermékeink közé tartoznak. ${ }^{32}$

31 COMTRADE, 2017.

32 Comtrade, 2019. 


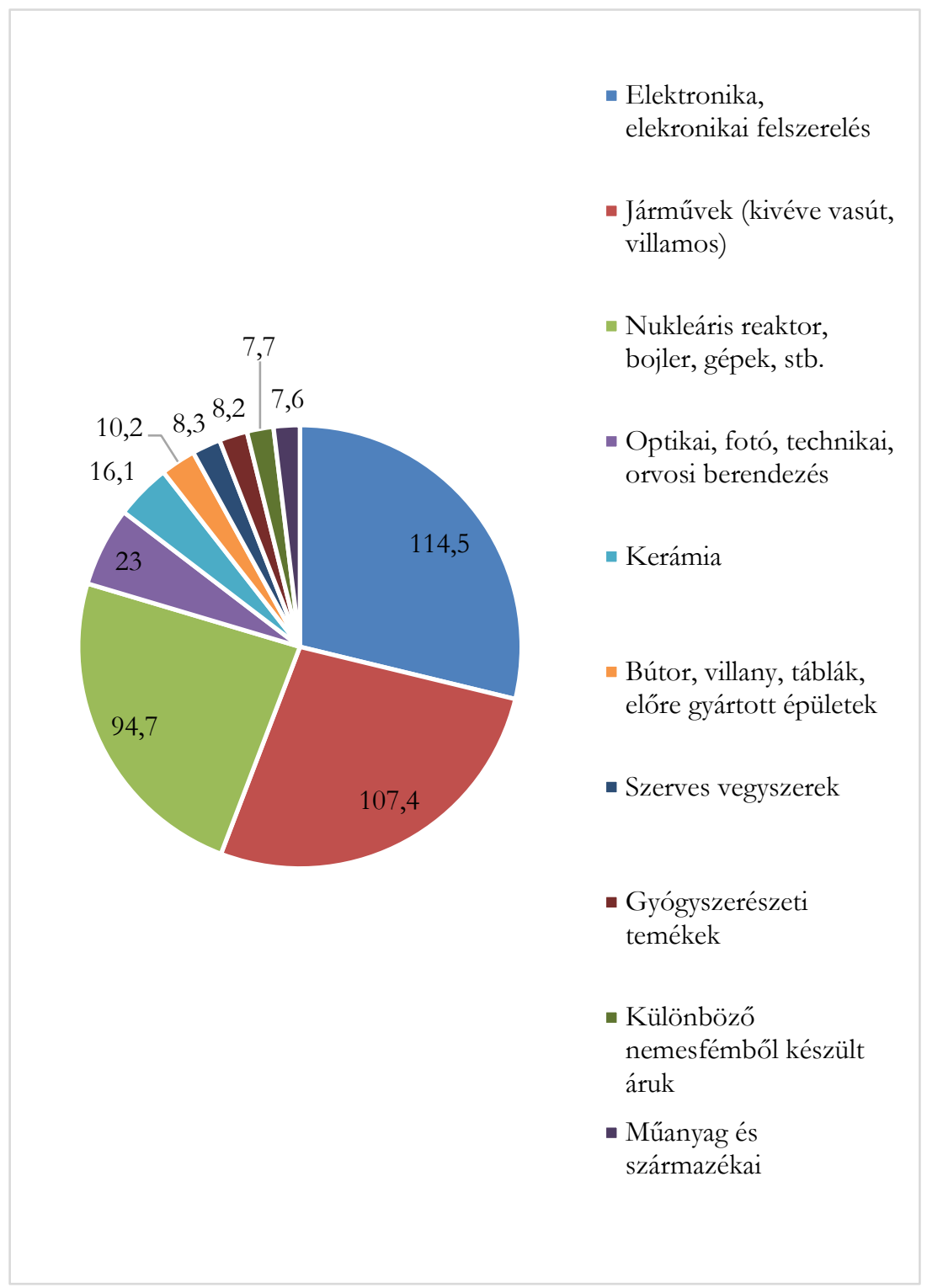

1. sz. ábra. A Dél-Koreába exportált magyarországi termékek eloszlása 2017-ben. Comtrade adatok alapján saját szerkesztés.

A Dél-Koreából Magyarországra exportált termékeket vizsgálva látszik, hogy a nukleáris reaktorokhoz kapcsolódó eszközök exportja az 
eddigi erős középmezőnyből 2015 óta az élre tört. A 2017-es értékéhez képest ez a szektor megkétszerezte exportmennyiségét, így 2018-ban 538,3 millió dollár értékben exportált Dél-Korea ilyen jellegű termékeket Magyarországra. Az elektronikai cikkek exportjának 2010 óta tartó folyamatos csökkenése 2018-ban megszakadt, míg a Magyarországról Koreába történő elektronikai cikkek exportja az utóbbi években folyamatosan növekedett. Figyelemreméltó továbbá a koreai export szerkezetében bekövetkezett változás a gyógyszerészeti termékek vonatkozásában is. Ezen termékek 2014-ben csupán a tizedik, 2015-ben a harmadik, 2016-ban a negyedik legnagyobb volumenú exportcikkeként tartattak számon a Koreai Köztársaságban Magyarország felé. Ez a volumennövekedés 2014-rôl 2015-re valamivel több, mint 160 millió dollár volt $^{33}$. 2018-ban ezen termékek forgalma még tovább növekedve, 231,8 millió dollárral a negyedik legnagyobb értékben Magyarországra exportált terméke Dél-Koreának. ${ }^{34}$

33 COMTRADE, 2017.

${ }^{34}$ Comtrade, 2019. 


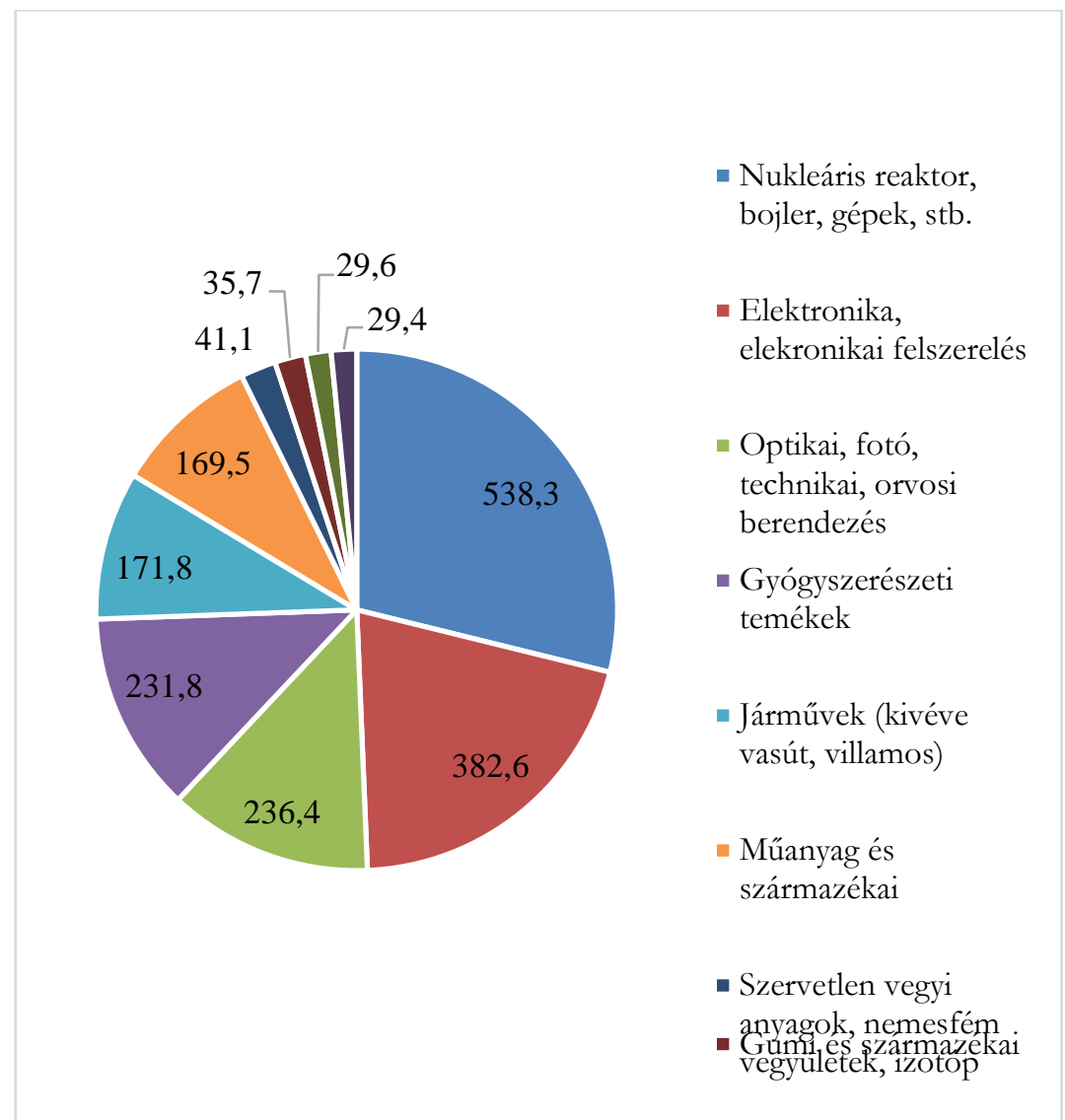

2. sz. ábra. A Magyarországra importált dél-koreai termékek eloszlása 2017-ben. Comtrade adatok alapján saját szerkesztés.

\subsection{Tőkebefektetések}

Dél-Korea az EU-n kívüli országok közül az egyik legnagyobb befektető Magyarországon ${ }^{35}$, de világviszonylatban is jelentős tőkebefektetőnek számít. A közvetlenül befektetett dél-koreai tőke 2017 végén 1,6 milliárd euró volt, ami az utóbbi 5 évben történt több, mint fél milliárd eurós növekedés végeredménye. 2015 óta évente hozzávetőlegesen 200 millió euróval nő a dél-koreai közvetlenül befektetett tôke

${ }^{35} \mathrm{Az}$ adatok nem tartalmazzák a speciális célú vállalatokat. Az ilyen típusú adatok 2008-as kezdettel elérhetőek. Forrás: MNB, 2019. 
Magyarországon. 2017-ben az összes külföldi befektetett tőke 2,2\%-át adta Dél-Korea.

A magyar befektetések a Koreai Köztársaságban szintén figyelemreméltó összegeket tesznek ki. Magyarországról 2017 végén összesen 539 millió eurónyi tôkét fektettek be Dél-Koreában, míg ez 2008ban csupán 271,3 millió euró volt. 2015 óta évente átlagosan 40 millió euróval nő a magyar tôkebefektetés Dél-Koreában. A teljes magyarországi tőkekihelyezés 2,15\%-át jelentették 2017 végén a dél-koreai befektetések ${ }^{36}$. A végsô befektető ${ }^{37}$ ország szerinti kimutatások alapján a dél-koreai gazdasági szereplők a 2016. évi külfölditőke-állomány 1,8\%-áért felelősek 1,36 milliárd euró értékben. 2016-ban a dél-koreai közvetlen befektetések Magyarország külfölditőke-állományának 1,9\%-a - 1,45 millió euró köthető a dél-koreai gazdasági szereplőkhöz.

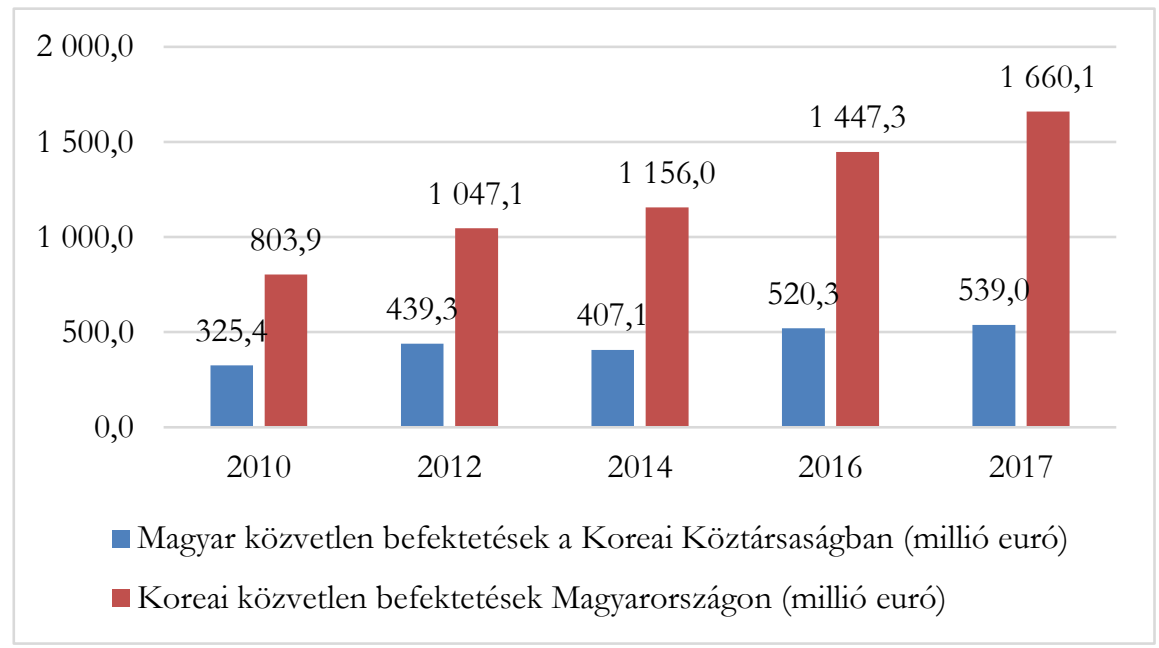

3. sz. ábra. Közvetlenül befektetett tőke az adott év végén (speciális célú vállalati adatok nélkül) a két ország között. Magyar Nemzeti Bank adatai alapján saját szerkesztés.

\footnotetext{
${ }^{36}$ COMTRADE, 2019.

37 A vállalatcsoport tulajdonosi láncának csúcsán lévő többségi - az adott vállalkozásban közvetve vagy közvetlenül 50\% feletti szavazati joggal rendelkező - befektetőt, amely fölött más befektető nem gyakorol ellenőrzést (nincs további $50 \%$ feletti szavazati joggal rendelkező tulajdonosa).
} 


\subsection{A forint és a koreai von (won) alakulása}

Az elmúlt időszakban változás következett be a koreai von és a magyar forint árfolyamát illetően: a 2008-2010-es időszakkal ellentétben a 2010 és 2015 közötti időszakra a forint éves átlagárfolyamának folyamatos gyengülése volt jellemző a vonnal szemben. Ez a folyamat azonban 2015 óta jelentős mértékben lelassult, illetve 2016-ban és 2017-ben a forint erősödött a vonnal szemben - a 2018 év végi adatok alapján 100 von 24,54 forintot ért átlagosan az azt megelőző évben. Ez a 2007-es értékekhez képes a von 24,1\%-os erősödését jelenti, a 2015-ös értékekhez képest azonban a von 0,6\%-os romlását jelenti a forinttal szemben. A von korábbi erősödése annak is köszönhető, hogy míg a forint az euróval szemben $27 \%$-kal, addig a von csak 2\%-kal értékelődött le 2008 és 2018 között. ${ }^{38}$ Az elmúlt időszakban újabb erőteljes változás következett be: 100 dél-koreai von 2020 októberében 26.36 forintot ért, miközben a forint az euróval szemben is gyengülő tendenciát mutat huzamosabb idő óta - egy euró jelenleg ugyanis 360 forint körüli összeget ér. ${ }^{39}$

A fent részletezett adatok alapján látható, hogy a 2015-ös nyilatkozatban megfogadott gazdasági kapcsolatok szorosabbra füzése eddig legalábbis - megvalósulni látszik, amely hazánk szempontjából gazdaságilag mindenképpen előnyös, ám Dél-Korea gazdaságára is jótékony hatással van.

\section{KULTURÁLIS KAPCSOLATOK}

\subsection{Az oktatással kapcsolatos kezdeményezések}

Az elmúlt évtized jelentős előrelépéseket hozott a dél-koreai-magyar kapcsolatokat illetően. A gazdasági megállapodásokhoz magas szintű látogatások is párosultak: a magyar fél részéről 2015-ben Áder János köztársasági elnök és Semjén Zsolt miniszterelnök-helyettes, 2016-ban Kövér László, az Országgyúlés elnöke is elutazott Dél-Koreába.

A dél-koreai-magyar kapcsolatok egy másik hajtóerővel is rendelkeznek, ezt pedig egy kulturális találkozási folyamatnak nevezhetjük. Ennek fontos eleme a koreai nyelv és kultúra oktatása Magyarországon: már

\footnotetext{
$38 \mathrm{MNB}, 2019$.

${ }^{39}$ Portfolio, 2020.
} 
1989 szeptemberében elindult a koreai nyelvoktatás a Külkereskedelmi Főiskolán. A kezdeményezés létrejöttében fontos szerepe volt Hidasi Judit professzornak, illetve Osváth Gábor föiskolai docensnek is. Birtalan Ágnes egyetemi docens vezetésével 1997-ben az Eötvös Loránd Tudományegyetem bölcsészkarán elkezdődött a négy féléves koreai program, majd 2008-ban megalakult az ELTE Koreai tanszék, elsőként alapképzési kínálattal, amit 2012-ben mesterképzési lehetőség követett - miközben cél a doktori képzés általánossá tétele is. ${ }^{40}$ Nem elhanyagolható a 2012-ben nyílt budapesti Koreai Kulturális Központ tevékenysége sem, mely nyelvtanfolyamok, kulturális kurzusok, illetve különböző események és kiállítások szervezése által ismerteti meg Koreát az érdeklődőkkel. ${ }^{41}$ Külön kiemelendő a Koreai Filmfesztivál, mely 2020-ban már tizenharmadik alkalommal került megrendezésre - még a koronavírus-járvány nehézségeinek ellenére is. A rendezvénysorozat a Koreai Köztársaság Nagykövetségének támogatásával indult 2007-ben. ${ }^{42}$ Érdekesség, hogy Dél-Koreában is oktatnak magyar nyelvet: a Hankuk Egyetemen (Hankuk University of Foreign Studies) 1998 óta múködik magyar tanszék, jelenleg két magyar lektor jelenlétével. A tegui (Daegu) Keimyung Egyetem (Keimyung University) Liszt Intézete 2009-ben kezdte meg múködését, a Kodálymódszer tanítását és népszerűsítését vállalva a budapesti Zeneakadémia tanárainak támogatásával. ${ }^{43}$

\subsection{A „koreai hullám” hatása}

A kulturális közeledéshez a legtöbbet az 1990-es években indult úgynevezett koreai hullám jelensége adott hozzá. A dél-koreai populáris kultúra különböző elemei - filmek, televíziós sorozatok, popzene, divat, gasztronómia - egyre népszerúbbé váltak a világ különböző tájain, így Magyarországon is. ${ }^{44}$ A magyar fiatalok fogékonyak a koreai popkultúrára, annak ellenére, hogy hazánkban a nyugat-európai országokhoz képest később karolták fel annak különböző elemeit. Az első szinkronos koreai sorozat, „A palota ékköve” 2008-ban indult Magyarországon, az elmúlt tíz

\footnotetext{
40 ELTE TÁVOL-KELETI INTÉZET, 2019.

${ }^{41}$ KOREAi Kulturális KÖZPONT, 2019.

42 KoreAi FILMFESZTIVÁL, 2018.

${ }^{43}$ LISZT ACADEMY, 2019.

44 Dél-Korea úgynevezett puha hatalmával (angol elnevezés: soft power) kapcsolatosan bővebben lásd: FEKETE, 2019.
} 
évben pedig nyolc koreai sorozat jutott el különböző magyarországi televíziós csatornákra, miközben a médiaszolgáltató platformokon keresztül több tucat koreai film és sorozat elérhető. Lee Dangkweon, a budapesti Koreai Kulturális Központ igazgatója úgy látja, van valami különös a magyar közönségben, amikor koreai filmekkel vagy sorozatokkal találkozik: „A Koreai Filmfesztivál fontos esemény sqámunkra, minden évben rendkivül sokan érdeklödnek iránta. Érdekes, hogy a magyar közönség nagyon könnyen megérti a koreai filmek, müsorok történetsqálait, az alkotás hordozta üzenetet. A nyugati nézőók részéröl sokkal inkább az a visszajelzés érkezik, hogy nehéz követni a cselekménysorozatot. Szerintem ez. annak köszönhetö, hogy Magyarországnak és Koreának nagyon basonló történelme van. Mindkét nép történelmét átjárta a fájdalom, a szabadság iránti harc, illetve a hazáért való kemény küzdelem". ${ }^{45}$

Filmek tekintetében nagy tapasztalattal rendelkezik Czibolya Kálmán filmtechnikus is, aki 2003 óta tizenkét alkalommal járt Dél-Koreában. Elmondása szerint egy évvel ezt megelőzően kezdődött el a távol-keleti ország iránti rajongása: "Valóban, amikor 2002-ben a Japán és Dél-Korea által közösen rendezett labdarúgó-világbajnokság szöuli záróünnepségét láttam a televizióban (...) azt gondoltam, mindenképp el akarok jutni Dél-Koreába. Látni akartam azokat az arcokat, a gyerekeket, fiatalokat, az idöseket, és rajtuk keresztül mindenképp szerettem volna megismerni a kultúrájukat: a tradicionális dobosokat, táncaikat, énekeiket, dalaikat, öltözetüket, és mindent, ami Koreával kapcsolatos. Azt gondolom, hogy ez egy régóta szunnyadó dolog volt bennem..." Czibolya Kálmán ezt követően 2003 nyarán meghívta a Szöuli Nemzetközi Ifjúsági Filmfesztivál két vezetőjét az általa szervezett magyarországi gyermek és ifjúsági filmes fesztiválra, majd 2003 augusztusában az Anszogban megrendezésre kerülő Nemzetközi Ifjúsági Filmes Múhely résztvevője volt. "2019 januárjában az elsö alkalommal megrendezett Andongi Nemzetközi Filmtábor kiemelt meghivottja voltam, ahol nyolc országból érkezett középiskolás nemzetközi résztvevönek tartottam kameratechnika órát. Görögországból, Spanyolországból, Tajvanról, Kinából, Japánból, Németországból, Magyarországról és Dél-Koreából is érkeztete fiatalok. Ez nagy megtisz̧teltetés, de egyben óriási felelösség is volt számomra." - mesélte Czibolya Kálmán, akinek példája jelzi, hogy milyen szintű együttmúködést eredményezhet az, ha egyetlen személy hisz valamiben, ugyanis a közremúködése nélkül a makói fiatalok talán nem jutottak volna el Dél-Koreába: "Minden egyes alkalommal csodálom a koreai fiatalok kreativitását, alázatát, szorgalmát, tehetségét. Fantasztikus dolog velük dolgozni. A tizenhat év alatt

45 A szerző által készített interjú része. 
rengeteg ismerösre, barátra, tanítványra tettem szort, akikekel a mai napig élö kapcsolatom van. Az elmúlt tizenhat évben a Makói Videómübely közel buszonöt alkotója utazhatott Dél-Koreába ezekre a filmes mübelyekre, táborokba, s több mint negyven DIMA-s diake vett részt Zoom to Europe és Asia Express fesqutiváljainkon Magyarországon, Makón, és a rendezvényeinkhez társult környezö településeken". 46

Azon túl, hogy szakmai munkát végzett Koreában, Czibolya Kálmán egy közel 5000 főt számláló magyar Facebook csoport egyik vezetője is. A közösséghez bárki csatlakozhat, aki érdeklődik Dél-Korea iránt: "Azt gondolom, ebhez. [a Korea iránti egyre nagyobb külföldi érdeklódésnek] köze van annak, bogy Dél-Korea egyre nyitottabbá vált, s népszerüek a kosztümös történelmi, jelenkori sorozataik. (...) Az sem mellékes, hogy nem csak a tinik körében egyre népszerübb a koreai popzene, a K-pop. Ezt legszemléletesebben a 2017 márciusában Torontóban átélt SHINee nagykoncert illusztrálta sqámomra, abol körülbelül ötezren voltak: azt kell mondanom, hogy a visitozó rajongók egy része már rég kinötte tini cuccait... (...) Emellett azt gondolom, hogy Korea a kulturális értékeivel, hagyományaival, kisugárzásával olyan dolgokat, élményeket ad például egy európai kulturrkörböl érkezônek, amelyek azután egy csapásra Korea-rajongóvá tebetik az, „óvatlanokat". De az. egyre több Koreával foglalkozó közöosségi oldal, s az azokon sqereplö sqemélyes élményeket visszaadó fotók, filmek is mind-mind olyan üzeneteket sugároznak, közvetitenek az arra fogékonyak sqámára, bogy ezt az orsqágot, kultúrát, equeket embereket mind többen szeretnék személyesen is megismerni, befogadni. Erre én is csak. birtatni, bátoritani tudok mindenkit!"

\subsection{A kulturális egyensúly hiánya}

A kulturális ismerkedést illetően nincs egyensúly, hisz a koreai hullámmal ellentétben a magyar elemek egyelöre nem tudtak hasonló gyorsasággal terjedni Dél-Koreában. Ennek ellenére több hungarikum is megjelent az országban. Ilyenek például a magyar sütemények, melyek a több mint 150 éves történelemmel rendelkező Gerbeaud Kávéházban fogyaszthatóak Szöulban. A magyar cukrászda a világ ötödik legmagasabb épületében, az 555 méter magas Lotte World Tower felhőkarcolóban található. ${ }^{47}$ Népszerú a klasszikus zene és a színház: létezik többek között egy koreai Liszt-társaság is. Előadásokra Korea-szerte sor került az elmúlt évek folyamán, különös tekintettel a 2019-es jubileumi évforduló idején.

\footnotetext{
46 A szerző által készített interjú része.

47 THE KOREA Times, 2015.
} 
2019. január 17-én például a Magyar Állami Operaház és a Tegui Operaház közremúködésében Erkel Ferenc Bánk bán címú operája csendült fel. A harmincéves ünnepségekhez tartozik továbbá, hogy a KTX expresszvonatok fedélzeti magazinjának januári számában interjú volt olvasható Csoma Mózes nagykövettel. ${ }^{48}$ Két hónappal később egy újabb fontos eseményre került sor, a nagykövet átadta ugyanis a Nemzeti Hangul Múzeum (National Hangeul Museum) számára az első koreai-magyar szótárt, melyet 1957-ben publikáltak Budapesten ${ }^{49}$ A budapesti Koreai Kulturális Központ szintén nagyobb volumenû programokat szervezett szeptemberben, mely keretén belül egy virtuális utazáson keresztül volt lehetőség megismerkedni a koreai gasztronómiával és kalligráfiával, de hagyományos koreai tánc csapatok és modern zenét játszó bandák is szórakoztatták a közönséget. A budapesti koreai nagykövet, Choe Kyu-Sik egy közel 20 perces koreai televíziós műsorban beszélt a 30 éves évforduló kapcsán. A nagykövet az évfordulóra tervezett programokon túl több Magyarországgal kapcsolatos érdekességről is szót ejtett, például a meglepően magas számú magyar Nobel-díjasok számáról, illetve a magyar tudósok által kitalált innovációkról. A műsor során a koreai nézők mind a Koreai Kulturális Központ által szervezett eseményekről, mind pedig Budapest nevezetességeiről láthattak rövid montázsokat. ${ }^{50}$

\subsection{A turizmus adta kulturális lehetőségek}

A valódi utazásokat illetően Lee Dangkweon szerint a magyar kormány feladata kampányok által népszerűsíteni az országot: „Egyelöre még sok koreai keveset tud Magyarországról. Kis dolgokra van szüleség, olyanokra, melyek elsöre nem tünnek lényegesnek, de hatalmas áttörést eredményez̧hetnek. Tavaly DélKoreában kerülttek megrendezésre a téli olimpiai játékok. A magyar Liu testvérek. [Liu Shaolin Sándor és Lin Shaoang rövidpályás gyorskorcsolyáróke] rendkivül jól teljesitettek, sok koreai pedig teljesen meg volt örülve értük. (...) Meg kell ismertetni Magyarországot a koreaiakkeal, hisz az eddigi tapasztalatok alapján a látogatók nagyon szeretik Budapestet, a város épitészetét, a gyógyfürdőket, a magyar édességeket és borokat. (...) Azt gondolom azonban, bogy a vidéki magyar belyszinek is elnyernék a

\footnotetext{
${ }^{48}$ KTX, 2019.

49 YONHAP NEWS, 2019.

${ }^{50} \mathrm{KTV}, 2019$.
} 
tets飞ésüiket, viszont ismeret biányában ritkán választanak Budapesten kivüli belysqineket." 51

Bár a Magyarországra utazó koreai turisták száma évről évre növekszik, a 2016-os adatok alapján a látogatók átlagosan csak egy és fél éjszakát töltöttek el az országban, kizárólag szinte a Budapest-Közép-Dunavidéken. Ennek egyik oka, hogy a koreai turisták általában utazási irodák úgynevezett ,package tour" ajánlataival élnek, melyek nem kizárólagosan Magyarországot célozzák meg, hanem Nyugat-Közép-Európa főbb látványosságait. A függetlenül utazó turisták is sokszor választanak inkább Európa-túrát, mivel a kontinensre való repülőút költséges. Fontos azonban megjegyezni a Budapest és Szöul közötti közvetlen légi járat hiányát, mely egy másik lehetséges oka volt annak, hogy a koreai látogatók csak rövid ideig tartózkodtak Magyarországon. Csoma Mózes szöuli magyar nagykövet is megjegyezte a közvetlen járat fontosságát, egyik legnagyobb nagyköveti ambíciójának épp ennek létrehozását jelölte ki, a magyar porcelántermékek és világszínvonalú borok hírének elterjesztésével egyetemben. ${ }^{52}$

2016-ban az Asiana Airlines közremúködésével ideiglenesen létezett közvetlen járat Budapest és Szöul között - a Boeing 777-200ER típusú gépek körülbelül tizenkét óra alatt tették meg az utat -, azonban a járat később megszűnt, annak ellenére, hogy magas szintű volt a repülőgépek kihasználtsága. ${ }^{53}$ 2017-ben arról is szó esett, hogy a Jin Air fapados délkoreai légitársaság 2019-tôl kezdve indítana járatokat Zágrábba és Budapestre $^{54}$, azonban hivatalos bejelentés azóta nem történt. A 30 éves diplomáciai kapcsolatok talán legnagyobb gyakorlati öröme mégis az a hír volt, mely a LOT lengyel légitáraság Budapest és Szöul közötti közvetlen járatáról tett bejelentést. Bár a LOT azóta sem szüntette meg az útvonalat, a koronavírus-járvány értelemszerűen komoly visszaesést eredményezett a kereslet terén, ahogy nagy bizonytalanságra ad okot a következő hónapok, akár évek lehetőségei kapcsán is. ${ }^{55}$ Fejlődésre azért is szükség van, mert a Magyarországról Dél-Koreába utazók száma alacsony, átlagosan a havi ezer főt sem éri $\mathrm{el}^{56}$. 2013-tól van lehetőség azonban Working and Holiday (WHS) vízumot kérni Dél-Koreába: az igénylők által elnyert vízum egy évre

\footnotetext{
51 A szerző által készített interjú része.

52 The Korea Times, 2015.

${ }^{53}$ HVG, 2016.

${ }^{54}$ BUDFLYER, 2019.

${ }^{55}$ Koreanista, 2019.

${ }^{56}$ KTO, 2019.
} 
szól, és munkavállalói engedélyt is tartalmaz, elsősorban szezonális, vendéglátói és egyéb alkalmi munkák teljesítésére. ${ }^{57}$ Sajnálatos módon a COVID-19 pandémiás helyzet ezen lehetőség kihasználását is erősen korlátozza.

\section{KONKLÚZIÓ}

Magyarország és a Koreai Köztársaság a XX. század második felének nagy részében egymástól merőben eltérő politikai, gazdasági és kulturális úton haladt. Ennek ellenére a két ország közötti diplomáciai kapcsolatok kialakulása a vártnál korábban és gyorsabban valósult meg, ehhez pedig mindkét állam nyitottságára és kezdeményezőkészségére szükség volt. A bilaterális kapcsolatok a 30 év során kedvező és pozitív irányba haladtak, ám a fejlődés intenzitása változó volt. Úgy tűnik azonban, hogy az elmúlt évtized fókuszváltást eredményezett: a keleti nyitás külpolitikai elve Magyarország számára újra lényegessé tette Dél-Koreát, miközben DélKorea gyors és erőteljes gazdasági fejlődését követően egyre fontosabbnak tartotta a közép-európai országokkal való jó kapcsolatok ápolását, Magyarország kapcsán pedig egy stabil partnerre talált.

A jelen tanulmányban vizsgált politikai, gazdasági és kulturális elemek is felhívják azonban a figyelmet az egyensúly hiányára. Ezen elemek alapján egy olyan jelenség vehető észre, mely alapján kimondható, hogy jelenleg Magyarország számára többet jelent Dél-Korea, mint fordítva. Az arányok eltolódása észrevehető a két ország közötti exportmérlegben, a befektetések mértékében, ahogy abban is, hogy a koreai kultúra különböző elemei sokkal nagyobb hatást gyakoroltak hazánkra, mint a magyar kultúra Dél-Koreára. Érdemes azonban azt is megjegyezni, hogy Dél-Korea innovatív hozzáállása következtében globális kulturális terjedést tudott elérni, így hasonló folyamatok vehetőek észre a közép-európai országokkal való bilaterális kapcsolatainak egészét illetően.

Pozitív folyamat, hogy Magyarországon és Dél-Koreában is egyre szélesebb az a társadalmi réteg, mely kíváncsi a másik ország kultúrájára. Lehetséges tehát, hogy a magyar populáris kultúra elemei nem jutottak el Dél-Koreába - miközben a hagyományos kulturális elemek is csak egy szúk réteg körében ismertek -, viszont a dél-koreai emberek részéről érkező érdeklődés számos formában megmutatkozik, többek közötti az

57 WORKING HOLIDAY, 2019. 
idegenforgalomban is, ami maga után vonja a politikai kapcsolatok szorosabbra füzését is, illetve a gazdasági lehetőségek számának növekedését.

Magyarország feladata, hogy a dél-koreai innovatív szellemhez hasonlóan naprakész, vonzó kampányok által érje el a koreai társadalom különböző szegmenseit, miközben képes továbbfejleszteni országimázsát nemzetközi viszonylatban is. Külön kihívást jelent a magyar -dél-koreai kapcsolatok jövőjét illetően a koronavírus-járvány, ugyanis számos nézet szerint a pandémia következtében deglobalizációs folyamatok indulhatnak el, a két ország egymáshoz való képletes közeledését pedig ez nagyban gátolhatja. Mindazonáltal mindkét állam a körülményekhez képest sikeresen küzdött a járvány ellen - a Koreai Köztársaság világviszonylatban is az egyik legsikeresebb járványkezelést mutatta -, így joggal konzultálhat egymással a globális kihívás következményeiről, a legfőbb egészségügyi kihívások megoldási lehetőségeiről, illetve a gazdasági fellendülés lényeges lépéseiről.

\section{FELHASZNÁLT IRODALOM}

BUDFLYER (2019): Budapest és Szöul között indít közvetlen járatot a LOT, BudFlyer.

Elérhető:

https://budflyer.blog.hu/2019/04/04/budapest es szoul kozott indit kozvetlen jaratot a lot (Letöltve: 2019.04.15.)

ChinAembassy (2004): A kínai-magyar kétoldalú kapcsolatok. Elérhető: http://www.chinaembassy.hu/hu/zxgx/zzgx/t84598.htm (Letöltve: 2019.07.16.)

COMTRADE (2019): Hungary - Export to South Korea. Elérhető: https://comtrade.un.org/labs/dit-trade-

vis $/$ ?reporter $=348 \&$ partner $=410 \&$ type $=C \& y e a r=2017 \&$ flow $=2$ (2019.09.28.)

Comtrade (2019): South Korea - Export to Hungary. Elérhető: https://comtrade.un.org/labs/dit-tradevis $/$ ? reporter $=348 \&$ partner $=410 \&$ type $=$ C\&year $=2017 \&$ flow $=2$ (2019.09.28.)

Csoma Mózes (2012): Koreaiak Magyarországon az 1950-es években, Budapest, L'Harmattan Kiadó.

ELTE TÁVOL-KELETI INTÉZET (2019): Koreai tanszék - A koreanisztika Magyarországon.

Elérhető: 
$\underline{\text { http: } / / \text { tavolkeletiintezet.elte.hu/index.php?menu }=\text { szervezet\&almenu }=\mathrm{k}}$ oreaitanszek (Letöltve: 2019.03.09.)

Farkas, I., SZerdahelyi, I., Umemura, Y., Wintermantel, P. (2009) Tanulmányok a magyar japán kapcsolatok történetéből, ELTE Eötvös Kiadó Kft, Budapest

FÁbIAN, ARMin VinCENTIUS (2019): Íme a LOT videós bejelentése a Budapest-Szöul járatról.

Elérhető: https://koreanista.home.blog/2019/07/31/ime-a-lot-videos-bejelentesea-budapest-szoul-jaratrol/ (Letöltve: 2019.08.17.)

FEKETE ANETT (2019): A dél-koreai soft power: hallyu, Külügyi Múhely, 2019/1. szám. DOI azonosító: DOI: 10.36817/KM.2019.1.7

HVG (2016): Már közvetlen járattal indulhatunk Szöulba, Hvg.hu. Elérhetô: https://hvg.hu/kkv/20160704 asiana szoul kozvetlen jarat repulogep budapest airport?s=hk (Letöltve: 2019.03.15)

INDEX (2020): Több helyen is megemlékeznek ma az egy éve elsüllyedt Hableányról, Index.

Elérhetô: https://index.hu/belfold/2020/05/29/hableany hajobaleset megemlek ezes evfordulo/?fbclid=IwAR2715L8Rf5w-KjjNzoBCFrUBzn8iv5WDeGYJyhNtztBaqPcsKQrYBgewk (Letöltve: 2020.10.05.)

INTERNATIONAL MONETARY FUND (2020). Elérhető: https://www.imf.org/en/Countries/HUN (Letöltve: 2020.10.06.) INTERNATIONAL MONETARY FUND (2020). Elérhetô: https://www.imf.org/en/Countries/KOR (Letöltve: 2020.10.06.) JoEL, LEE (2018): Hungary can help inter-Korean ties, innovation with Central Europe, Koreaherald. Elérhető: http://www.koreaherald.com/view.php?ud=20181231000476 (Letöltve: 2019.03.14.)

Joint Statement, The Visegrad Group (2015). Elérhető: http://www.visegradgroup.eu/documents/official-statements/jointstatement-on-the (Letöltve: 2019. 06. 16.)

Korea Tourism Organization (2019). Korea, Monthly Statistics of Tourism.

Elérhető: https://kto.visitkorea.or.kr/eng/tourismStatics/keyFacts/KoreaMonthl yStatistics/eng/inout/inout.kto (Letöltve: 2019.04.09.)

KOREAI FILMFESZTIVÁL (2020): Fesztiváltörténet - Koreai filmfesztivál Magyarországon 2007-2018. http://www.koreaifilm.hu/fesztivaltortenet/ (Letöltve: 2020.10.05.) 
Koreai Kulturális KÖZPONT (2019). A Központról (Szolgáltatásaink). Elérhető: $\quad$ http://hungary.korean-culture.org/hu/948/contents/724 (Letöltve: 2019.03.09.)

KTV (2019): 한국-헝가리 수교 30주년..동유럽 한류문화의 거점이 되다 [세계 속 한국] (A koreai-magyar diplomáciai kapcsolatok 30 éve). Elérhető:

http://www.ktv.go.kr/news/latest/view?content $\mathrm{id}=569124 \& u n i t=265$ (Letöltve: 2019.04.11.)

KTX매거진 (2019): 수교 30주년 맞은 동유럽 우방국 헝가리 (Interjú a 30 éves kapcsolatokról).Elérhető: http://ktx.ecatalog.co.kr/home/view.php?host $=$ main\&site $=1901 \& \mathrm{fbcli}$ d=IwAR1 KdgW0RzWDXX IwMLzvvAMPceVO1wHh62GZbECD5T qwPhJYtSIRf8wigM (Letöltve: 2019.03.24)

KÖZPONTI STATISZTIKAI HivatAL (2018). Elérhető: http://www.ksh.hu/docs/hun/xftp/stattukor/mo delkorea kapcs.pdf (Letöltve: 2019. 07.07)

LeE, RACHEL (2015): Seoul has Hungarian desert café, The Korea Times. Elérhetô:

http://www.koreatimes.co.kr/www/nation/2018/12/176 184911.html (Letöltve: 2019.03.11.)

LISZT ACADEMY KODÁlY INSTITUTE (2019). Elérhető: https://kodaly.hu/study/short-courses-117132 (Letöltve: 2019.08.13.)
MAGYAR
NEMZETI
BANK
(2019).
Elérhető:

https://www.mnb.hu/statisztika/statisztikai-adatok-informaciok /adatok-idosorok/vii-

arfolyam?fbclid=IwAR30Q_azioWFwQo7uv7s75IGSfWfSjZoih1iF51G 7rqhhHBJZU4LqJ7COiw (Letöltve: 2019.08.12.)

MAgYARORSZÁg-JapÁN JubILEumi ÉV 2009 (2009): Japán-Magyar kapcsolatok. Elérhető: $\quad \underline{\text { https://www.hu.emb- }}$ japan.go.jp/2009/jphu link h.html\#1 seiji (Letöltve: 2019.07.14.)

MAGYARORSZÁG KORMÁNYA (2019): Soha nem voltak olyan jók a magyarkínai kapcsolatok, mint most. Elérhető: https://www.kormany.hu/hu/kulgazdasagi-eskulugyminiszterium/hirek/soha-nem-voltak-olyan-jok-a-magyar-kinaikapcsolatok-mint-most (Letöltve: 2019.07.16.) 
MagyarorszÁg NAgYKÖVETSÉge SZÖUl: KulturÁlis KAPCSOlatoK. Elérhetô: https://szoul.mfa.gov.hu/hun/page/kulturalis-kapcsolatok (Letöltve: 2019.03.09.)

NÉPSZAVA (2019): Tíz percük maradt a túlélésre - szakértő a Hableány katasztrófájáról, Népszava. Elérhető: https://nepszava.hu/3037829 tizpercuk-maradt-a-tulelesre--szakerto-a-hableany-katasztrofajarol (Letöltve: 2019.06.16.)

OECD

Elérhető:

https://data.oecd.org/korea.htm?fbclid=IwAR3waqO5W2txUoaU9BJs7 CaDAY2MeFy8NlG8JQr aDjNg 7VO81NVRoH8nE (Letöltve: 2019.08.12.)

OECD (2019): Real GDP forecast. Elérhető: https://data.oecd.org/gdp/real-gdpforecast.htm?fbclid=IwAR1W7MYBEeNiQVZYHrQJ7CO 3IT7UBw5 9IkcS1Q7VHYEkTeWPaCoMWjuksw (2020.09.28.)

ORIGO (2015): Szorosabbá fűzné a gazdasági kapcsolatokat Dél-Koreával Áder János, Origo.

Elérhetô: https://www.origo.hu/nagyvilag/20150414-szorosabba-fuzne-agazdasagi-kapcsolatokat-del-koreaval-ader-janos.html 2019.06.16.)

PORTFOlio (2020): Esik tovább a forint, 361 felett az euró. Elérhető: https://www.portfolio.hu/deviza/20200917/esik-tovabb-a-forint-361felett-az-euro-449072 (Letöltve: 2020.10.06.)

RÉSZLET A SZERZŐ BESZÉLGETÉSÉBŐL CZIBOLYA KÁLMÁN FILMTECHNIKUSSAL, Budapest, 2019.

RÉSZLET A SZERZŐ BESZÉLGETÉSÉBŐL I DANG KVON IGAZGATÓ ÚRRAL, Budapest, 2019.

TARjÁN M. TAMÁs (2017): A panmindzsoni fegyverszünettel véget ér a koreai háború, Rubicon. Elérhetô: http://www.rubicon.hu/magyar/oldalak/1953 julius 27 a panmindzso ni fegyverszunettel veget er a koreai haboru (Letöltve: 2019.05.31.)

TORZSA ISTVÁN (2009): A magyar-dél-koreai diplomáciai kapcsolatok normalizálása, az elmúlt húsz év eredményei, Külügyi Szemle, 2019.1. Teleki László Intézet Külpolitikai Tanulmányok Központja, 8 (1): 222227 (Letöltve: 2019.06.15.)
UN
COMTRADE
DATABASE
(2017).
Elérhető:

https://comtrade.un.org/labs/dit-trade- 
vis $/$ ?reporter $=348 \&$ partner $=410 \&$ type $=C \& y e a r=2017 \&$ flow $=2$ (Letöltve: 2019.08.12.)

WORKING HOLIDAY (2019). Elérhető: https://workingholiday.hu/ (Letöltve: 2019.04.09.)

연합뉴스 (2019): 국립한글박물관, 헝가리 최초 한글사전 기증받아 (Szótár adományozása a Nemzeti Hangul Múzeum számára). Elérhető: https://www.yna.co.kr/view/AKR20190321116400005?section=culture $\% 2$ Fall\&fbclid $=$ IwAR3n5Z9evvC3XdghaYc'T-

geF5AyqO2XRqTOozO6P8EwaktqqAek92LELHxQ

(Letöltve: 2019.03.22.) 